\title{
CRYSTALLINE ADMIXTURES AND THEIR EFFECT ON SELECTED PROPERTIES OF CONCRETE
}

\author{
JiŘí PAZDERKa, Eva HáJKová* \\ Department of Building Structures, Faculty of Civil Engineering, CTU in Prague, Thákurova 7, 166 29 Prague, \\ Czech Republic \\ * corresponding author: eva.hajkova@fsv.cvut.cz
}

ABstract. There have been many experimental measurements of the waterproofing ability and durability of concrete with a crystalline admixture, but some other important properties have not been reliably tested yet. The results of the tests, carried out by the authors, showed that crystalline admixtures reduce the water vapor permeability of concrete by $16-20 \%$. The authors also carried out the water pressure test in different time intervals, during the initial phase of cement hydration. The test results have shown that the full waterproofing effect of concrete with a crystalline admixture is available approximately on the 12th day after the concrete creation. The crystalline admixture effect on the compressive strength of concrete was also the subject of the testing. The results have shown that the compressive strength of the concrete with a crystalline admixture (added in an amount of $2 \%$ ) and the compressive strength of the specimens from concrete without admixture were almost identical after 28 days.

KEYWORDS: crystalline admixture; concrete; building envelope; water tightness; permeability.

\section{INTRODUCTION}

The protection of buildings against subsurface water and moisture is a significant part of the building design. Crystalline materials are often used to protect the underground parts of a building against moisture and subsurface water. There are several methods of the application of crystalline materials into the concrete structure: surface-applied coating or spraying, repairing and sealing mortars and integral waterproofing admixtures. The waterproofing admixture is designed for newly constructed buildings with the foundation structure from waterproof concrete. The crystalline admixture consists of Portland cement, specially treated quartz sand and a compound of ,active chemicals". The chemical composition of active chemicals in the crystalline material is kept confidential by all producers. The crystalline material's waterproofing effect in concrete is achieved by the reaction of various chemical components, which are contained in the solution, when combined within the concrete matrix [1. The process works only when the porous system of concrete reaches a sufficient level of moisture. Therefore, perfect moistening of the new concrete structure surface is very important. In the case of a shortage of moisture inside the concrete structure, the crystalline admixture's components lie dormant.

There were also many experimental laboratory measurements of the waterproofing ability of the crystalline admixture in the past, focused on verifying the waterproofing in various modifications [2 12$]$ and the durability [13 15] of concrete with crystalline admixtures. The results of these tests are very convincing, thus the water impermeability and high durability of concrete with crystalline admixtures may be declared.
Also, the results of its application to particular buildings and building constructions are, in most cases, conclusive [16-18]. The waterproofing effect of the crystalline admixture is conditioned on a strict technological discipline, especially the thorough curing of a fresh concrete [19].

The waterproofing ability and durability of the concrete with crystalline admixtures have been verified by many experimental measurements (as described above), but some other properties of crystalline admixtures have not been credibly described yet. There are uncertainties about the speed of the waterproofing effect, caused by the crystalline admixture in concrete. Furthermore, the changes in the water vapor permeability of concrete due to crystalline admixtures have not been credibly described yet. Water vapor permeability is a very important feature of each enveloping building structure, because a structure with low water vapor permeability is a potential risk in terms of surface condensation. All producers of crystalline admixtures declare that their admixtures do not reduce the water vapor permeability of concrete (some of them even present the water vapor permeability of concrete with their admixture). However, there is a missing comparison of these data with data for the same (reference) concrete without admixtures. Another problem is the fact that all available measured values of water vapor permeability were made on a commercial basis (presented by the producers of crystalline materials). For the comprehensive evaluation of crystalline admixtures, it is necessary to consider their effect on the compressive strength of concrete, not only their waterproofing ability (the compressive strength is the basic parameter of each bearing concrete structure).

The producers of crystalline admixtures declare 

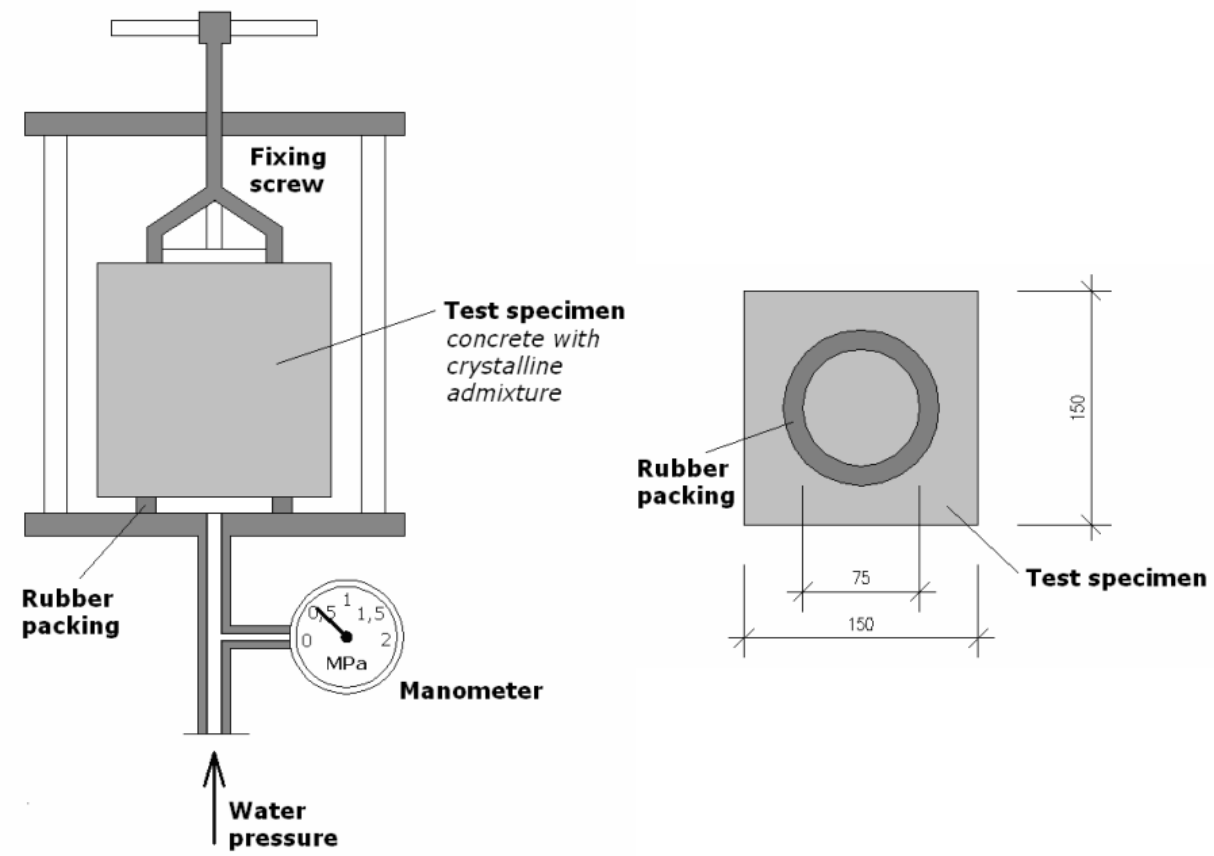

FiguRE 2. The test arrangement.

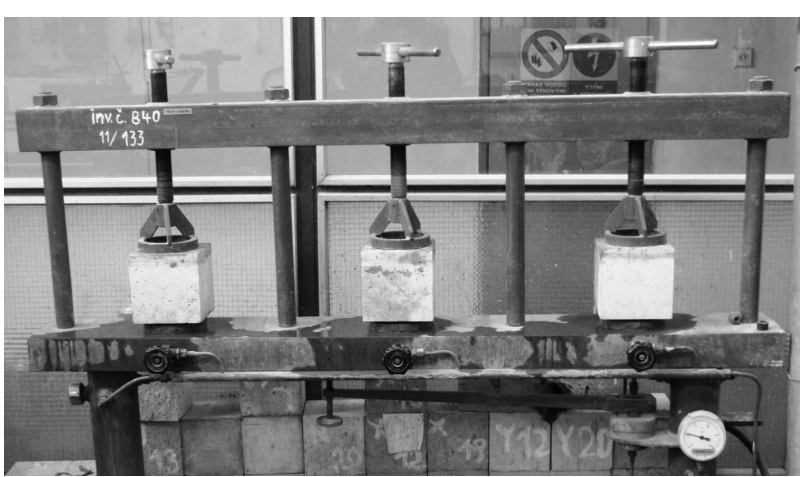

FiguRE 1. Specimens in the test apparatus.

that their admixtures do not reduce the compressive strength of concrete. Many of them even say that their admixture mildly increases the compressive strength of concrete, but a credible comparison of these affirmations with the compressive strength results of the same (reference) concrete without admixtures is missing (the results are only compared with the projected strength of concrete). The following article attempts to describe aforementioned unverified properties of crystalline admixtures.

\section{THE SPEED OF THE WATERPROOFING EFFECT}

\subsection{MAterials AND Methods}

There is different information regarding the time effect of crystalline admixtures from various producers. Each producer presents different data about the time of the beginning of the waterproofing effect (the time

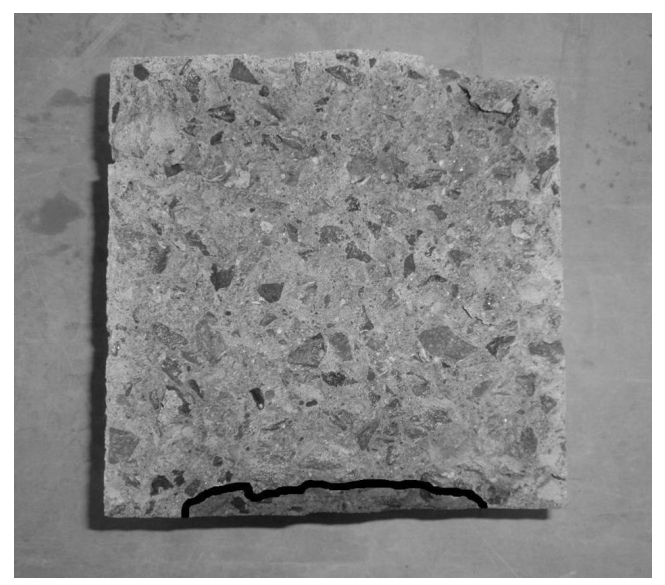

Figure 3. A broken test specimen with a visible boundary of seepage.

when the concrete is waterproof), without having exact measurements from a recognized laboratory. The aim of the experiment was to carry out the water pressure test in different time intervals during the initial phase of cement hydration. The water pressure test was conducted in accordance with the standard EN 12390-8 [20], taking into account open literature [21]. The test specimens had a size of $150 \times 150 \times 150 \mathrm{~mm}$ and were made of $\mathrm{C} 16 / 20$ concrete with the Xypex Admix C-1000 NF crystalline admixture. 21 specimens were prepared for the test -3 pieces for each tested time period. The crystalline admixture was added directly to the mixing water before mixing the other components in (in amount of $2 \%$ of cement weight). The test specimens were prepared in accordance with the standard EN 12390-2 [22]. The measurements were 


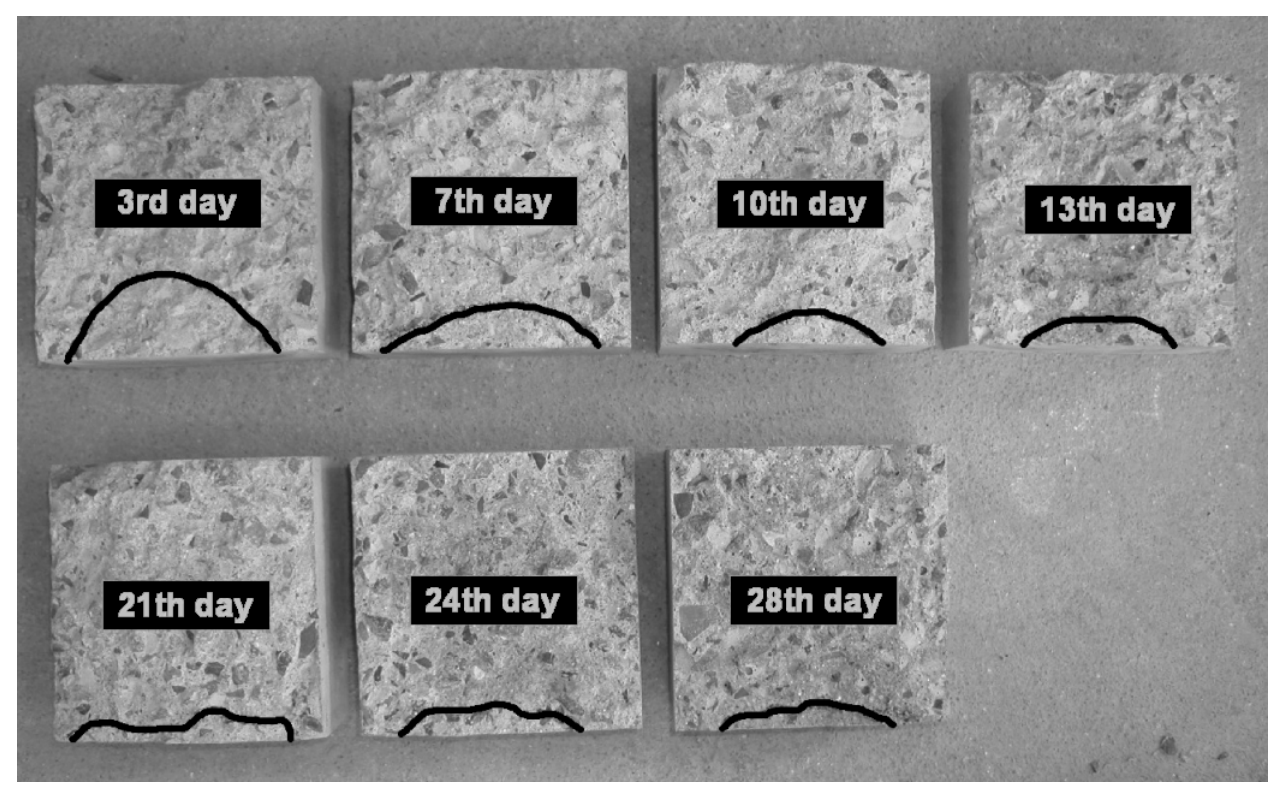

Figure 4. The seepage shape in various time periods after the creation of specimens.

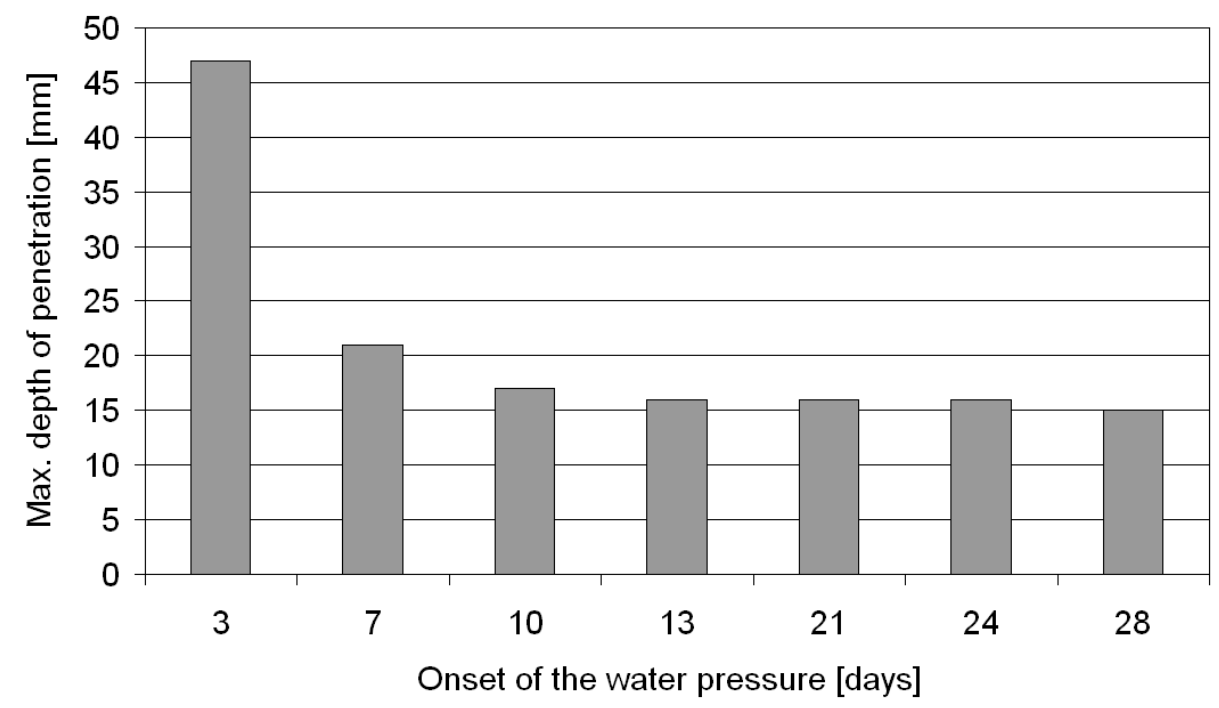

FiguRE 5. Relation between seepage and loading time.

carried out in various time periods after the creation of the specimens. Each test cube was loaded by a $0.5 \mathrm{MPa}$ water pressure and stayed in the equipment for 72 hours (Figs. 1 and 2). After this time, the cubes were broken up and the seepage was measured (Fig. 3).

\subsection{ReSUlts AND DISCUSSION}

The test results of the time-sequential water pressure tests (Figs. 4 and 5 have shown that the full waterproofing effect of concrete with a crystalline admixture is available approximately on the 12 th day after the concrete (test specimen) creation. At that time, the seepage boundary is about $15 \mathrm{~mm}$ away from the specimen's surface and the waterproofing effect is, therefore, guaranteed. The concrete structure with a crystalline admixture could be (theoretically) ready for water loading already on the 12 th day after creation.

\section{The UnCERTAINTY REGARDING THE WATER VAPOR PERMEABILITY}

\subsection{MATERIALS AND METHODS}

The water vapor permeability of a building material in EN ISO 12572 [23] is defined by the water vapor resistance factor $\mu(-)$. There are 2 basic methods for the water vapor resistance factor measurement that are described in [23]: the „dry cap" method and the „wet cap" method. The „wet cap" method was chosen as appropriate in this case, because the presumed level of the surrounding air humidity was $\varphi \geq 60 \%$. The principle of the „wet cap" method is the following: The test specimen is placed between two environments with different levels of air humidity: $\varphi_{1}=95 \%$, 


\begin{tabular}{cccc}
\hline Type of specimen & $\begin{array}{c}\text { Type of crystalline } \\
\text { admixture }\end{array}$ & $\begin{array}{c}\text { Water vapor resis- } \\
\text { tance factor } \mu(-)\end{array}$ & $\begin{array}{c}\text { Water vapor perme- } \\
\text { ability comparison }\end{array}$ \\
\hline Concrete with admixture & Penetron Admix & 85 & $120 \%$ \\
Concrete with admixture & Xypex Admix C-1000 & 82 & $116 \%$ \\
Concrete & - & 71 & $100 \%$ \\
\hline
\end{tabular}

TABLE 1. Results of the water vapor resistance factor $\mu(-)$.

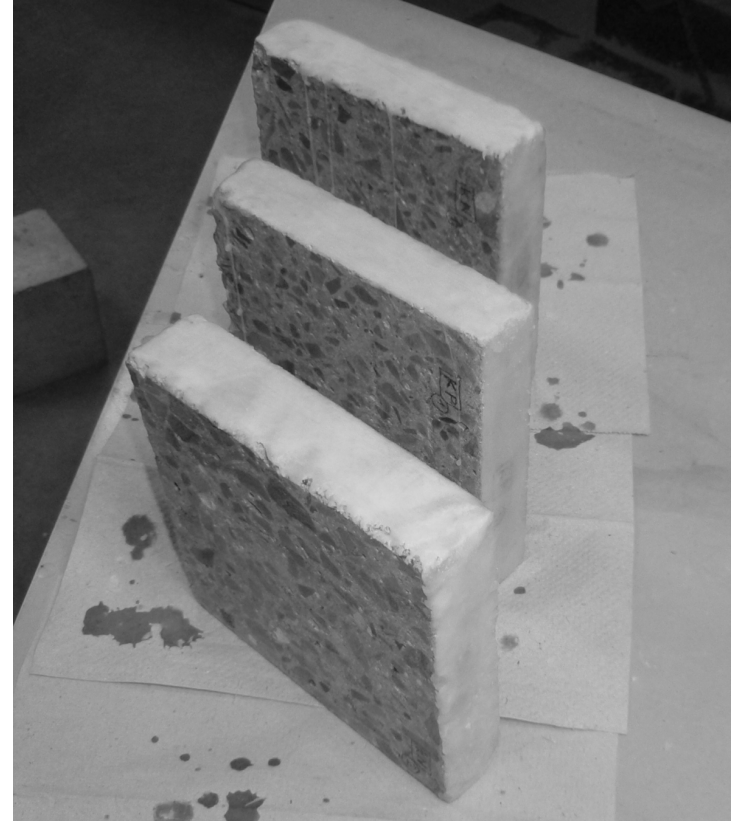

Figure 6 . The test specimen (with paraffin).

$\varphi_{2}=50 \%$. The laboratory measurement was carried out with concrete with crystalline admixture from 2 different variousvariousproducers: Penetron Admix and Xypex Admix C-1000 and, furthermore, with reference concrete without any admixture. 9 specimens were tested in total ( 3 for each aforementioned material). All the test specimens had sizes of $150 \mathrm{x}$ $150 \times 30 \mathrm{~mm}$ and were created by cutting from the standard test cube prepared in accordance with EN 12390-2 22. 4 sides $(150 \times 30)$ of the specimens were sealed with paraffin to ensure one-dimensional water vapor transmission (Fig. 6). After that, each specimen was placed in a glass bowl with $\mathrm{Ba} \mathrm{Cl} 2+2 \mathrm{H} 2 \mathrm{O}$ $\left(\varphi_{1}=95 \%\right)$ and deposited into the climatic chamber $\left(\varphi_{2}=50 \%\right)$. The airtight connection between the specimen and the glass bowl was secured through a silicone sealant (Fig. 7). The principle of the test was to measure the weight loss of the test set and find a steady quantity of the permeating water vapor per the time unit $G(\mathrm{~kg} / \mathrm{h})$. The process of measuring is shown in Fig. 8 .

\subsection{Results AND Discussion}

The water vapor resistance factor $\mu(-)$ of the tested concrete was calculated, according to EN ISO 12572 [23], from the values of the diffusion flow $G$ $(\mathrm{kg} / \mathrm{h})$, the relative humidity of the environment on

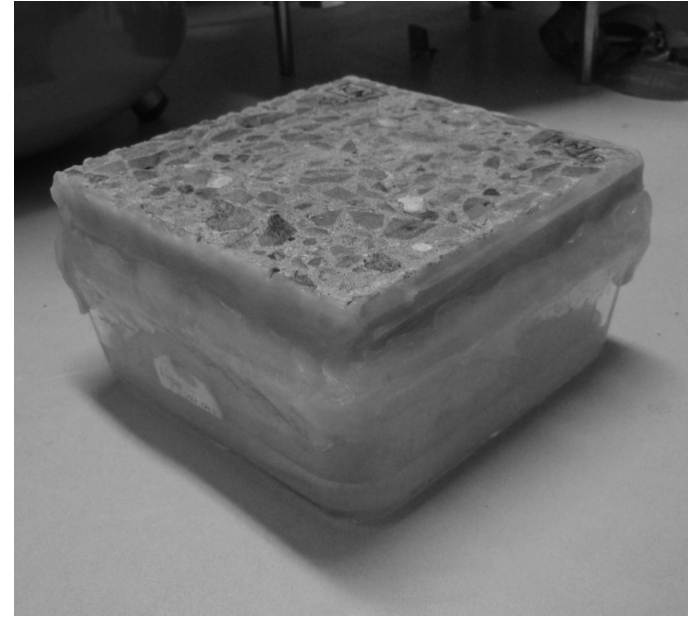

Figure 7 . The test set (specimen placed on the glass bowl).

both sides of the specimen $\varphi(\%)$, the temperature during the test $\theta\left({ }^{\circ} \mathrm{C}\right)$, the dimensions of the specimens $(\mathrm{mm})$ and the thickness of the air layer between the specimen and the surface of the solution inside the bowl. The resulting values of the water vapor resistance factor $\mu(-)$ are shown in Table 1. The results of experimental measurements have shown that the crystalline admixture reduces the water vapor permeability of concrete by $16 \%$ (Xypex) $20 \%$ (Penetron).

\section{The CRYSTAlline ADMiXTURE EFFECT ON THE CONCRETE'S COMPRESSIVE STRENGTH}

\subsection{Materials AND Methods}

For a deeper understanding of the crystalline admixture effect on the compressive strength of concrete, the strength test with two selected admixtures was performed according to EN 12390-3 [24]. The aim of the measurement was a compressive strength comparison between concrete with an admixture and the reference concrete. The measurement was carried out on cube-shaped specimens $(150 \times 150 \times 150 \mathrm{~mm})$, which were prepared according to EN 12390-2 [22]. C20/25 concrete and crystalline admixtures Penetron Admix and Xypex Admix C-1000 NF were chosen for the test. 9 specimens were tested in total (3 for each aforementioned material). The compressive strength test EN 12390-3 24] was carried out 28 days after the specimens creation (Fig. 9). The results of the compressive strength test are shown in Table 2 


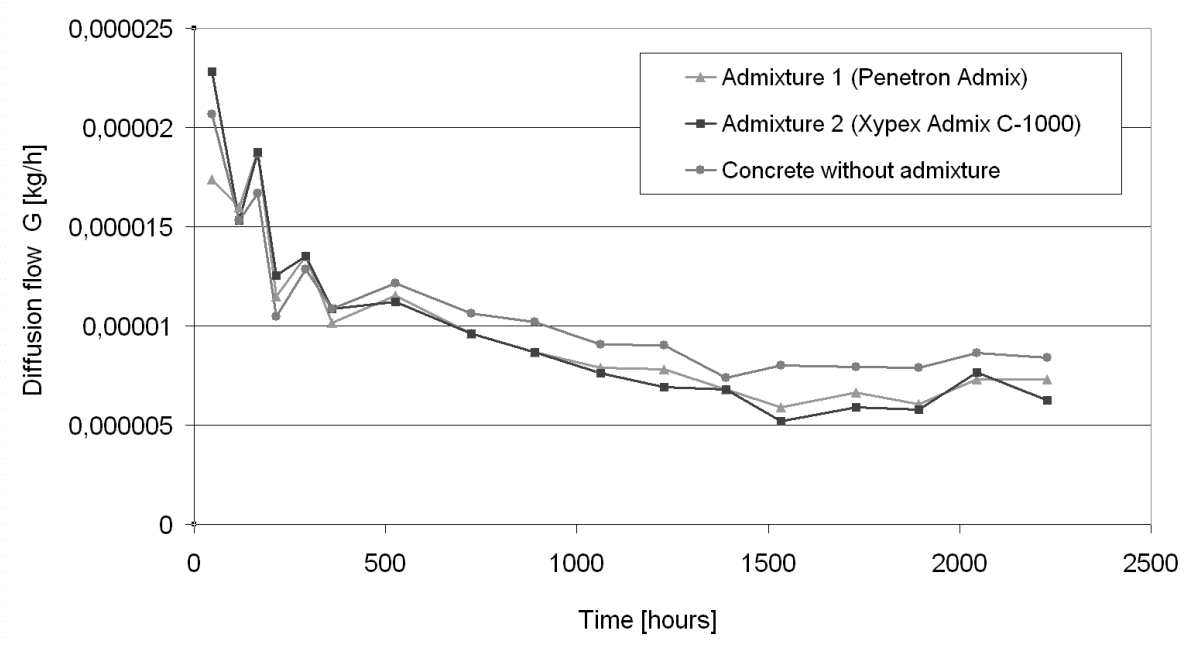

Figure 8. Diffusion flow of water vapor through the specimens during the test.

\begin{tabular}{lccccc}
\hline Concrete & Crystalline admixture & \multicolumn{3}{c}{ Compressive strength (MPa) } \\
\cline { 3 - 5 } & & \multicolumn{3}{c}{ Specimen } & Mean \\
\cline { 3 - 4 } & & 1 & 2 & 3 & \\
\hline C $20 / 25$ & Penetron Admix & 35.6 & 35.8 & 37.1 & 36.2 \\
C $20 / 25$ & Xypex Admix C-1000 NF & 37.2 & 35.7 & 36.1 & 36.3 \\
C $20 / 25$ & without admixture & 37.6 & 36.9 & 36.0 & 36.8 \\
\hline
\end{tabular}

TABLE 2. Results of the compressive strength test.

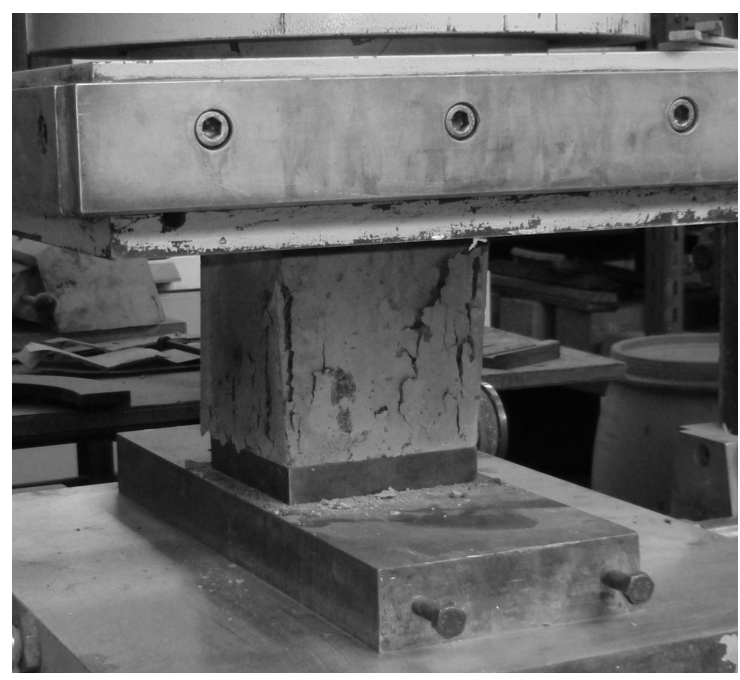

FiguRE 9. Loading of test specimen in a hydraulic press.

\subsection{Results And Discussion}

The results have shown that the compressive strength of the concrete with a crystalline admixture (added in an amount of $2 \%$ ) and the compressive strength of the specimens from concrete without admixture were almost identical after 28 days. It was surprising, given the declaration of some crystalline materials producers that their admixtures mildly increase the compressive strength of concrete. After the evaluation of the results and their consultations with experts from practice, the following hypothesis (assumption) was derived: The crystalline admixture added in an amount of $2 \%$ of the cement weight apparently caused a mild deceleration of the hardening of concrete. Even though the admixture increases the compressive strength, this effect occurs later than after 28 days. However, this hypothesis must be confirmed by subsequent testing.

\section{Conclusions}

The results of the laboratory testing of the speed of the waterproofing effect, caused by the crystalline admixture in concrete, have shown that the concrete structure with a crystalline admixture could be (theoretically) ready for water loading already on the 12 th day after creation. For the practical use, it is possible to say that the concrete structure with a crystalline admixture has a guaranteed waterproofing ability after the standard hardening time of concrete (28 days), regardless of the fact that the tested concrete with admixture showed waterproofing effect after 12 days (worse conditions are expected on the actual building site, therefore, there is a risk of a slower onset of the waterproofing).

The laboratory measurement has shown that the crystalline admixture reduces the water vapor permeability of concrete by $16 \%$ (Xypex) to $20 \%$ (Penetron). However, these are relatively negligible values, which should not cause any failure of the structure due to moisture. Overall, it is possible to say that the effects 
of crystalline materials on the water vapor permeability of concrete are insignificant.

It is probable that a crystalline admixture, added in an amount of $2 \%$ of the cement weight, caused a mild deceleration of the hardening of concrete (during the first 28 days). It was an interesting finding, given the declaration of crystalline materials producers that their admixtures mildly increase the compressive strength of concrete. It is, therefore, likely that even though the admixture increases the compressive strength, this effect occurs later than after 28 days. Based on these results, the crystalline admixture application in smaller amounts than the amount of $2 \%$ of the cement weight can be recommended (depending on producer's documentation which determines the minimum amount of an admixture to ensure a waterproof ability of concrete).

All the aforementioned claims are absolutely valid only for tested crystalline admixtures (Xypex, Penetron), but due to the very similar substance of other crystalline admixtures (Vandex, Maxseal, Sikkaton, Masterseal, Krystol), it is possible to expect similar properties of concrete with these admixtures.

\section{ACKNOWLEDGEMENTS}

This work was supported by the Technology Agency of the Czech Republic under Grant no. TA03010501.

\section{REFERENCES}

[1] Rahhal, V. et al.: Scheme of the Portland cement hydration with crystalline mineral admixtures and other aspects. Silicates Industriels, 74(11), 2009, p. 347-352. Scopus: 2-s2.0-73649090808.

[2] Pazderka, J.: Crystalline coating or crystalline admixture? Concrete, 48(3), 2014, p. 20-21. Scopus: 2-s2.0-84899565383.

[3] Reiterman, P., Bäumelt, V.: Long-term sorption properties of mortars modified by crystallizing admixture. Advanced Materials Research, 1054, 2014, p. 71-74. DOI:10.4028/www.scientific.net/AMR.1054.71

[4] Bohus, S., Drochytka, R., Taranza, L.: Fly-ash usage in new cement-based material for concrete waterproofing. Advanced Materials Research, 535-537, 2012, p. 1902-1906. DOI:10.4028/www.scientific.net/AMR.535-537.1902

[5] Wang, K., Hu, T., Xu, S.: Influence of permeated crystalline waterproof materials on impermeability of concrete. Advanced Materials Research, 446-449, 2012, p. $954-960$. DOI:10.4028/www.scientific.net/AMR.446-449.954

[6] Zhou, M.R. et al.: Study on experiment of concrete compounding XYPEX and steel fiber. Applied Mechanics and Materials, 105-107, 2012, p. 1755-1759. DOI:10.4028/www.scientific.net/AMM.105-107.1755

[7] Dao, V.T.N. et al.: Performance of permeability-reducing admixtures in marine concrete structures. ACI Materials Journal. 107(3), 2010, p. 291-296. WOS: 000278352700010.

[8] Connell, L.: Crack Repair System Stops Water in Its Tracks. Concrete International, 29(5), 2007, p. 50-52.
[9] Yuers, K.: Chemical waterproofing more than skin deep. Concrete Engineering International, 8(1), 2004, p. 36-37. Scopus: 2-s2.0-1842612606.

[10] Munn, R.L., Kao, G., Chang, Z.T.: Performance and compatibility of permeability reducing and other chemical admixtures in Australian concretes. Proceedings of 7th CANMET/ACI Int. Conference on superplasticizers and other chemical admixtures in concrete, 2003, p. 361-379.

[11] Shaozhu, X.: Research and development of cementbased permable crystallization type waterproof materials abroad. China Building Waterproofing, 6, 2001.

[12] Edvardsen, C.: Water Penetrability and Autogenous Healing of Separation Cracks in Concrete. Betonwerk und Fertigteil-Technik, 62(11), 1996, p. 77-85. Scopus: 2-s2.0-0030282534.

[13] Bohus, S., Drochytka, R.: Cement based material with crystal-growth ability under long term aggressive medium impact. Applied Mechanics and Materials, 166-169, 2012, p. 1773-1778. DOI:10.4028/www.scientific.net/AMM.166-169.1773

[14] Jianxin, W., Liping, G.L.: Influence of Shenkebao permeable crystalline admixture on concrete resistance to chemical corrosion and freeze-thaw cycles. Jiangsu Building Materials, 2, 2010.

[15] Scancella, T., Robert, J.: Use of Xypex admixture to concrete as an inhibitor to reinforcement steel corrosion. Proceedings of the Materials Engineering Conference, 2, 1996, p. 1276-1280. Scopus: 2-s2.0-0030401904.

[16] Pazderka, J., Reiterman, P.: Depth impact of crystalline coating measured by electrical resistivity method, Concrete, 48(8), 2014, p. 20-21. Scopus: 2-s2.0-84924582698

[17] Klouda, F.: Concrete crystallisation gives India's greenest airport wings. Concrete, 44(3), 2010, p. 33-34. Scopus: 2-s2.0-77950576963.

[18] Klouda, F.: The Capri South Beach fully protected with crystalline waterproofing-admixture-treated concrete. Concrete Engineering International, 14(4), 2008, 59-60. Scopus: 2-s2.0-58249119627.

[19] Weng, T.L., Cheng, A.: Influence of curing environment on concrete with crystalline admixture. Monatshefte fur Chemie, 145(1), 2014, p.195-200. DOI:10.1007/s00706-013-0965-z

[20] EN 12390-8 Testing hardened concrete - Part 8: Depth of penetration of water under pressure. Brussels: European Committee for Standardization, 2008.

[21] Barnes, R.: Permeability Testing of Site Concrete. Camberley: The Concrete Society, 2008.

[22] EN 12390-2 Testing hardened concrete - Part 2: Making and curing specimens for strength tests. Brussels: European Committee for Standardization, 2009.

[23] EN ISO 12572 Hygrothermal performance of building materials and products - Determination of water vapour transmission properties. Brussels: European Committee for Standardization, 2001.

[24] EN 12390-3 Testing hardened concrete - Part 3: Compressive strength of test specimen. Brussels: European Committee for Standardization, 2009. 